\title{
Bibliographic references
}

1. Lepore, M. Urban microclimate parameters for buildings energy strategies [Text] / M. Lepore // Vitruvio International journal of Architecture Technology and Sustainability. 2016. - Vol. 1. - No. 2. - P. 1 - 11.

2. Alwetaishi, M. Effect of Microclimates Conditions on Architectural Design of Residential Buildings in Saudi Arabia European [Text] / M. Alwetaishi, A. Balabel // Journal of Advances in Engineering and Technology. - 2016. - Vol. 3. - No. 8. - P. 29 - 32.

3. Thakur, K. Urban Microclimate and Thermal Comfort in Buildings [Text] / K. Thakur, A. J. Sanyal // Challenges and Issues ARCHITECTURE - Time Space \& People. - 2014. - Vol. 3. - No. 6. - P. $24-29$.

4. Kuismanen, K. Climate-Conscious Architecture-Design And Wind Testing Method For Climates In Change [Text] / K. Kuismanen. - OULU Finland, 2008. - 445 p.

5. Беляев, Н.Н. Математическое моделирование массопереноса в горизонтальных отстойниках [Текст] / Н.Н. Беляев, В.А. Козачина. - Д.: Акцент ПП, 2015. - 114 с.

6. Беляев, Н.Н. Прогноз уровня загрязнения атмосферного воздуха в зоне влияния городских автомагистралей / Н.Н. Беляев, Т.И. Русакова, В.Е. Колесник, А.В. Павличенко // Науковий вісник Національного гірничого університету. - 2016. - № 1. - С. 90 - 97.

7. Марчук, Г.И. Математическое моделирование в проблеме окружающей среды [Текст] / Г.И. Марчук. - М. : Наука, 1982. - 320 с.

8. Численное моделирование распространения загрязнения в окружающей среде [Текст] / М.З. Згуровский, В.В. Скопецкий, В.К. Хрущ, Н.Н. Беляев. - К.: Наук. думка, 1997. -368 c.

Надійшла до редколегї 12.06.2018

УДК 532.3

\section{О.Г. Гоман, Т.М. Никулина}

Днепровский национальный университет имени Олеся Гончара

\section{УДАР КРУГЛОГО ТЕЛА О ПОВЕРХНОСТЬ ИДЕАЛЬНОЙ НЕСЖИМАЕМОЙ ЖИДКОСТИ}

В работе рассматривается задача в плоской постановке об ударе круглого тела о поверхность идеальной несжимаемой жидкости, не имеющей границ. Тело частично погружено в жидкость, а его погруженная часть имеет форму кругового сегмента. В некоторый момент времени происходит удар, после чего тело мгновенно получает поступательную скорость и вращательную скорость вокруг оси, перпендикулярной плоскости, в которой рассматривается течение. С помощью конформного отображения, переводящего область полуплоскости с вырезанным сегментом в полуплоскость, данная задача сводится к смешанной задаче Келдыша-Седова для верхней полуплоскости, решение которой известно в квадратурах. Таким образом, была решена ударная краевая задача со смешанными граничными условиями. Был найден комплексный потенциал жидкости в мгновение после удара, а также потенциал скорости жидкости на участке соприкосновения тела с жидкостью. Полученные результаты проанализированы в случаях влияния на жидкость со стороны тела только одной компоненты скорости, либо всех трех компонент. Результаты были проиллюстрированы для различных углов погруженного сегмента и проведено сравнение с результатами для плавающей пластинки.

(C) Гоман О.Г., Никулина Т.М., 2018 
Показано, что после удара жидкость может начать двигаться безотрывно, однако, при некоторых значениях скорости тела может возникать отрыв жидкости от поверхности тела. Об этом свидетельствует тот факт, что значение потенциала на некоторой части поверхности тела становится положительным. На этом участке как раз и будет находиться точка отрыва. В этом случае полученные решения уже нельзя использовать, и следует рассматривать задачу с учетом возникновения зоны отрыва. В случае воздействия со стороны тела только вертикальной компоненты скорости при углах сегмента меньше 90 ${ }^{\circ}$ отрыв жидкости от поверхности тела возникать не будет.

Ключевые слова: несжимаемая жидкость, ударная задача, задача Келдыша-Седова, конформное отображение, комплексный потенциал.

В роботі розглядається задача в плоскій постановці про удар круглого тіла об поверхню ідеальної нестисливої рідини, яка не має границь. Тіло частково занурене в рідину, а його занурена частина має форму кругового сегмента. В певний момент часу відбувасться удар, після чого тіло миттєво отримує поступальну швидкість і обертальну швидкість навколо осі, перпендикулярної до площини, в якій розглядається течія. За допомогою конформного відображення, що переводить область півплощини 3 вирізаним сегментом у півплощину, дана задача зводиться до змішаної задачі Келдиша-Сєдова для верхньої півплощини, розв'язок якої в квадратурах відомо. Таким чином, була розв'язана ударна крайова задача зі змішаними граничними умовами. Було знайдено комплексний потенціал рідини у мить, що слідує безпосередньо після удару, а також потенціал швидкості рідини на ділянці дотику тіла 3 рідиною. Отримані результати проаналізовано у випадках впливу на рідину з боку тіла або тільки однісї компоненти швидкості, або всіх трьох компонент. Результати було проілюстровано для різних кутів зануреного сегмента і проведено порівняння 3 результатами для плаваючої пластинки. Показано, що після удару рідина може почати рухатися безвідривно, однак, при деяких значеннях швидкості тіла може виникати відрив рідини від поверхні тіла. Про це свідчить той факт, що значення потенціалу на деякій частині поверхні тіла стає додатним. На цій ділянці якраз і буде знаходитися точка відриву. У такому випадку отримані розв'язки вже не можуть бути використані і слід розглядати задачу з урахуванням утворення зони відриву. У разі впливу з боку тіла тільки вертикальної компоненти швидкості при кутах сегмента менше $90^{\circ}$ відрив рідини від поверхні тіла виникати не буде.

Ключові слова: нестислива рідина, ударна задача, задача Келдиша-Сєдова, конформне відображення, комплексний потенціал.

In this article the problem about the impact of a circular body on the surface of an ideal incompressible fluid that does not have boundaries is considered in a plane statement. The body is partially submerged in the liquid, and its submerged part has the shape of a circular segment. At some point in time a shock occurs, after which the body instantaneously receives translational velocity and rotational velocity about an axis that is perpendicular to the plane of flow. Using a conformal mapping that maps a half-plane domain with a cut segment into a half-plane, this problem reduces to a mixed Keldysh-Sedov problem for the upper half-plane, the solution of which is known in quadratures. In this way, the shock boundary value problem with mixed boundary conditions has been solved. The complex potential of the liquid flow after the impact has been found, as well as the potential of velocity of the liquid at the site of contact between the body and the liquid. The results obtained has been analyzed in cases of influence on the liquid from the body side of only one velocity component, or all three components. In addition, the results has been illustrated for different angles of the submerged segment and compared with the results for a floating plate. It is shown that the fluid flow can move around the body without interruption after the impact. However, at certain values of the velocity of the body, liquid can detach from the body. This is evidenced by the fact that the value of the potential on some part of the surface of the body becomes greater than zero. On this site just would be the point of separation. In this case, the obtained solutions can not already be used and the problem should be considered taking into account the occurrence of the separation zone. In the case of the impact on the part of the body only the vertical component of the velocity at segment angles of less than $90{ }^{\circ}$, separation of the liquid from the surface of the body will not occur.

Keywords: incompressible fluid, shock problem, Keldysh-Sedov problem, conformal mapping, complex potential. 
Постановка задачи. В работе рассматривается задача ударного взаимодействия тела с жидкостью, в условиях плавания тела на поверхности неограниченной идеальной несжимаемой жидкости. Задача рассматривается в плоской постановке, и часть тела, погруженная в жидкость, имеет форму сектора. Тело частично погружено в жидкость, ширина погруженной части равна $2 a$, угол между поверхностью жидкости и касательной к сектору в точках $A$ и $A_{l}$ равен $a$ (рис. 1). Пусть в некоторый момент времени происходит удар, после чего тело мгновенно получает вертикальную компоненту скорости $V$, горизонтальную скорость $U$ и вращательную скорость $\omega$ вокруг оси, перпендикулярной плоскости, в которой рассматривается течение. Требуется найти поле скоростей жидкости непосредственно после удара.

В рассматриваемой задаче удобно расположить систему координат так, чтобы жидкость находилась в верхней полуплоскости (рис.1).

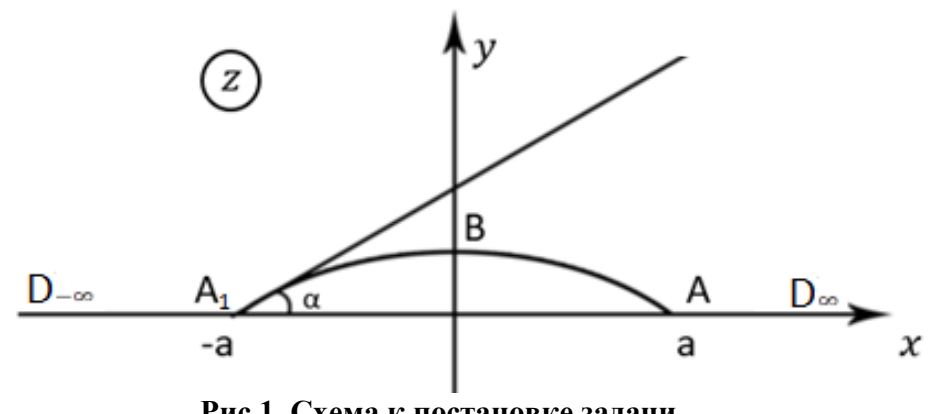

Рис.1. Схема к постановке задачи

Решение задачи. Как известно [4; 6], решение ударной краевой задачи описывается комплексным потенциалом $\mathrm{w}$ или характеристической функцией

$$
\chi=-\mathrm{iw}=\psi-\mathrm{i} \varphi,
$$

для определения которой имеем следующие граничные условия: на участках свободной границы $D_{-\infty} A_{1}$ и $A D_{\infty}$ задана функция $\varphi=0$; на поверхности тела $A_{1} B A$ задана функция тока $\psi(z)=U y-V x-\frac{\omega}{2}\left(x^{2}+y^{2}\right)$. Таким образом для функции $\chi$, имеем смешанную задачу Келдыша-Седова.

Для задачи Келдыша-Седова известно решение в виде квадратур для верхней полуплоскости. Чтобы им воспользоваться, нужно совершить такое конформное отображение, чтобы верхняя полуплоскость с лункой в физической области $z=x+i y$ отобразилась на верхнюю полуплоскость параметрической переменной $\zeta=\xi+i \eta$. При этом должно соблюдаться такое соответствие, чтобы точка $z=a$ переходила в точку $\zeta=1$, точка $z=-a-$ в точку $\zeta=-1$, точка $z=B$ - в точку $\zeta=0$, а точка $z=\infty-$ в точку $\zeta=\infty$ (рис. 2). 


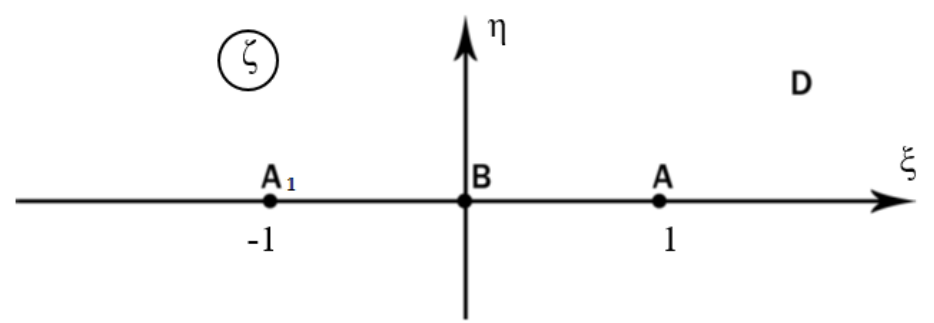

Рис. 2. Область параметрической переменной

Указанное конформное отображение будет иметь вид [4]:

$$
\zeta(z)=\frac{(z+a)^{\frac{\pi}{\pi-a}}+(z-a)^{\frac{\pi}{\pi-a}}}{(z+a)^{\frac{\pi}{\pi-a}}-(z-a)^{\frac{\pi}{\pi-a}}}
$$

Для обратного преобразования имеем формулу:

$$
z(\zeta)=a \frac{(\zeta+1)^{\frac{\pi-a}{\pi}}+(\zeta-1)^{\frac{\pi-a}{\pi}}}{(\zeta+1)^{\frac{\pi-a}{\pi}}-(\zeta-1)^{\frac{\pi-a}{\pi}}}
$$

Переформулированная задача Келдыша-Седова для верхней полуплоскости имеет следующую постановку. Определить функцию $\chi(z(\zeta))$ при $\operatorname{Im} \zeta>0$ с такими граничными условиями: на образе свободной поверхности $\varphi=0$ при $\infty<\xi<-1$ и $1<\xi<\infty, \eta=0$; а на образе поверхности тела $\psi(z(\zeta))=\psi(\zeta)$ при $-1<\xi<1, \eta=0$.

Применяя формулу конформного отображения, окончательно получим:

$$
\psi(\xi)=\frac{a}{F^{2}+2 F \cos \alpha+1}\left(-V\left(F^{2}-1\right)+2 F \sin \alpha(U+a \omega \operatorname{ctg} \alpha)\right)-\frac{a^{2} \omega}{2},
$$

при $\xi \in(-1 ; 1), \eta=0$,где

$$
F(\xi)=\left(\frac{1+\xi}{1-\xi}\right)^{\frac{\pi-a}{\pi}} .
$$

Решение задачи Келдыша-Седова для плоскости $\zeta$ имеет вид $[1,4,5]$ :

$$
\chi(\zeta)=-\mathrm{iw}=\psi-\mathrm{i} \varphi=\frac{-1}{\pi} \sqrt{\zeta^{2}-1} \int_{-1}^{1} \frac{\psi(t)}{\sqrt{1-t^{2}}} \frac{d t}{t-\zeta} .
$$

По формуле Сохоцкого [1] найдем, чему равно значение интеграла на верхней стороне отрезка $-1<\xi<1$ :

$$
\chi^{+}=\psi(\xi)-\frac{i}{\pi} \sqrt{1-\xi^{2}} \int_{-1}^{1} \frac{\psi(t)}{\sqrt{1-t^{2}}} \frac{d t}{t-\xi} .
$$


На этом участке функция $\psi$ задана граничными условиями, следовательно, остальная часть этой формулы есть функция - $i \varphi$, откуда для значения потенциала на поверхности тела в переменных $\zeta$ будем иметь выражение:

$$
\varphi(\xi)=\frac{1}{\pi} \sqrt{1-\xi^{2}} \int_{-1}^{1} \frac{\psi(t)}{\sqrt{1-t^{2}}} \frac{d t}{t-\xi} .
$$

Данный интеграл является интегралом типа Коши, который следует понимать в смысле его главного значения. Для вычисления потенциала скорости ф воспользуемся следующим алгоритмом вычисления интеграла Коши в смысле главного значения [1]:

$$
\varphi(\xi)=\frac{1}{\pi} \sqrt{1-\xi^{2}}\left(\int_{-1}^{1}\left(\frac{\psi(t)}{\sqrt{1-t^{2}}}-\frac{\psi(\xi)}{\sqrt{1-\xi^{2}}}\right) \frac{d t}{t-\xi}+\frac{\psi(\xi)}{\sqrt{1-\xi^{2}}} \ln \frac{1-\xi}{1+\xi}\right) .
$$

Согласно общим положениям теории присоединенных масс [6], имеем следующее выражение для $\varphi(\xi)$ :

$$
\varphi(\xi)=\varphi_{1} U+\varphi_{2} V+\varphi_{6} \omega,
$$

где

$$
\begin{aligned}
& \varphi_{1}=2 a \overline{\varphi_{1}} ; \varphi_{2}=2 a \overline{\varphi_{2}} ; \varphi_{6}=(2 a)^{2} \overline{\varphi_{6}} ; \\
& \overline{\varphi_{1}}=\frac{1}{2 \pi} \sqrt{1-\xi^{2}} \int_{-1}^{1} \frac{2 F(t) \sin \alpha}{F(t)^{2}+2 F(t) \cos \alpha+1} \frac{1}{\sqrt{1-t^{2}}} \frac{d t}{t-\xi} ; \\
& \overline{\varphi_{2}}=\frac{1}{2 \pi} \sqrt{1-\xi^{2}} \int_{-1}^{1} \frac{F^{2}-1}{F(t)^{2}+2 F(t) \cos \alpha+1} \frac{1}{\sqrt{1-t^{2}}} \frac{d t}{t-\xi} ; \\
& \overline{\varphi_{6}}=\frac{1}{4 \pi} \sqrt{1-\xi^{2}} \int_{-1}^{1}\left(\frac{2 F(t) \cos \alpha}{F(t)^{2}+2 F(t) \cos \alpha+1}-\frac{1}{2}\right) \frac{1}{\sqrt{1-t^{2}}} \frac{d t}{t-\xi} ; F(\xi)=\left(\frac{1+\xi}{1-\xi}\right)^{\frac{\pi-a}{\pi}} .
\end{aligned}
$$

Анализ результатов. Таким образом, найдено значение потенциала течения на теле, откуда можно найти импульсное давление, действующее на элементы поверхности тела со стороны жидкости. Импульсное давление с точностью до произвольной постоянной равно [3, 4]:

$$
P_{t}=-\rho \varphi \text {. }
$$

На рис. 3, 4, 5, 6 представлены результаты значений безразмерных функций $\overline{\varphi_{1}}, \overline{\varphi_{2}}, \overline{\varphi_{6}}$ для сегментов тела с различными углами $\alpha$ в зависимости от безразмерной координаты $\bar{x}=x / a$, где $x$ - абсцисса точки на поверхности сектора.

На рис. 3 изображены рассчитанные по полученным формулам графики $\overline{\varphi_{2}}(\bar{x})$. Здесь присутствует влияние только вертикальной компоненты скорости $V$ co стороны тела. Горизонтальная и вращательная компоненты скорости при этом равны нулю. Полученные результаты при $\alpha \rightarrow 0$ согласуются с данными для плоской пластины, ударяющую о свободную поверхность, [4]. 


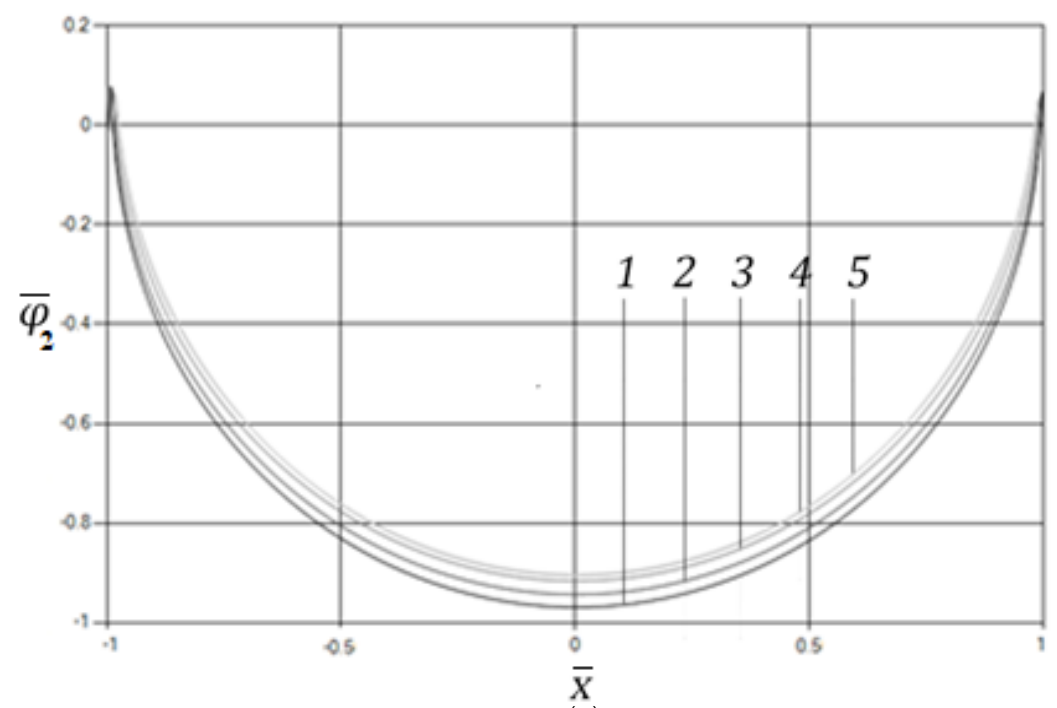

Рис. 3. Графики функции $\overline{\varphi_{2}}(\bar{x})$. для разных углов $\alpha$

(влияние вертикальной компоненты скорости $V$ ): $1-\alpha=5^{\circ} ; 2-\alpha=15^{\circ} ; 3-\alpha=30^{\circ} ; 4-\alpha=45^{\circ} ; 5-\alpha=60^{\circ}$

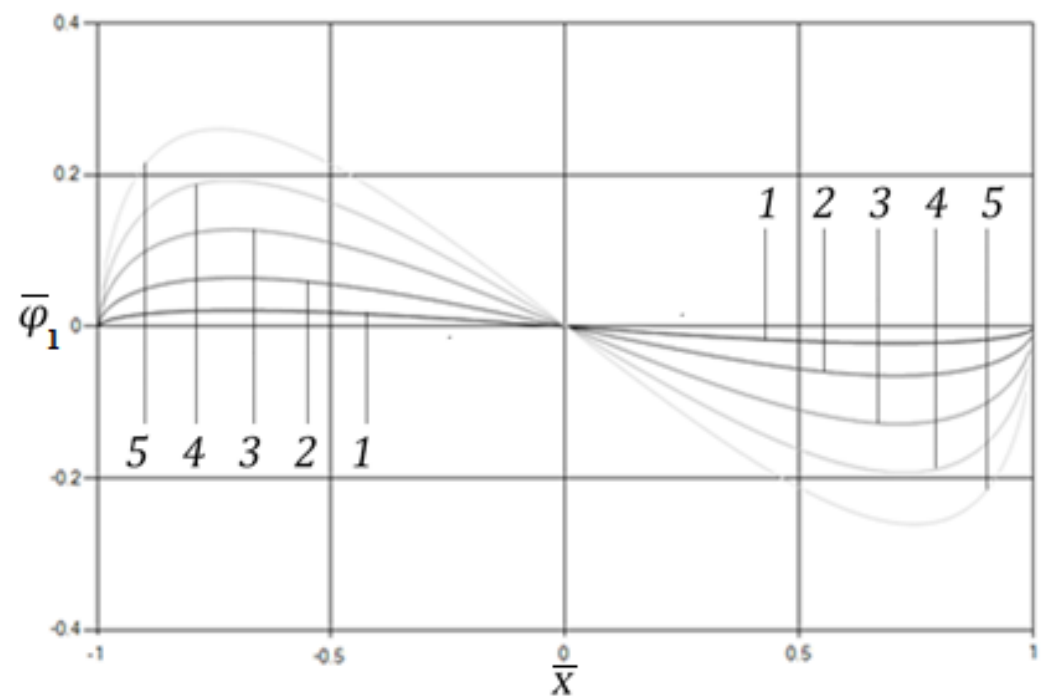

Рис. 4. Графики функции $\overline{\varphi_{1}}(\bar{x})$. для разных углов $\alpha$ (влияние горизонтальной компоненты скорости $U$ ): $1-\alpha=5^{\circ} ; 2-\alpha=15^{\circ} ; 3-\alpha=30^{\circ} ; 4-\alpha=45^{\circ} ; 5-\alpha=60^{\circ}$

На рис. 4 изображены графики $\overline{\varphi_{1}}(\bar{x})$. Здесь присутствует только влияние горизонтальной компоненты скорости U со стороны тела. На рис. 5 изображены графики $\overline{\varphi_{6}}(\bar{x})$. Здесь присутствует только влияние вращательной компоненты скорости $\omega$ со стороны тела. Результаты для значений функции $\overline{\varphi_{6}}$ при $\alpha \rightarrow 0$ согласуются с данными для плоской пластины, подверженной мгновенной угловой скорости, [2]. 


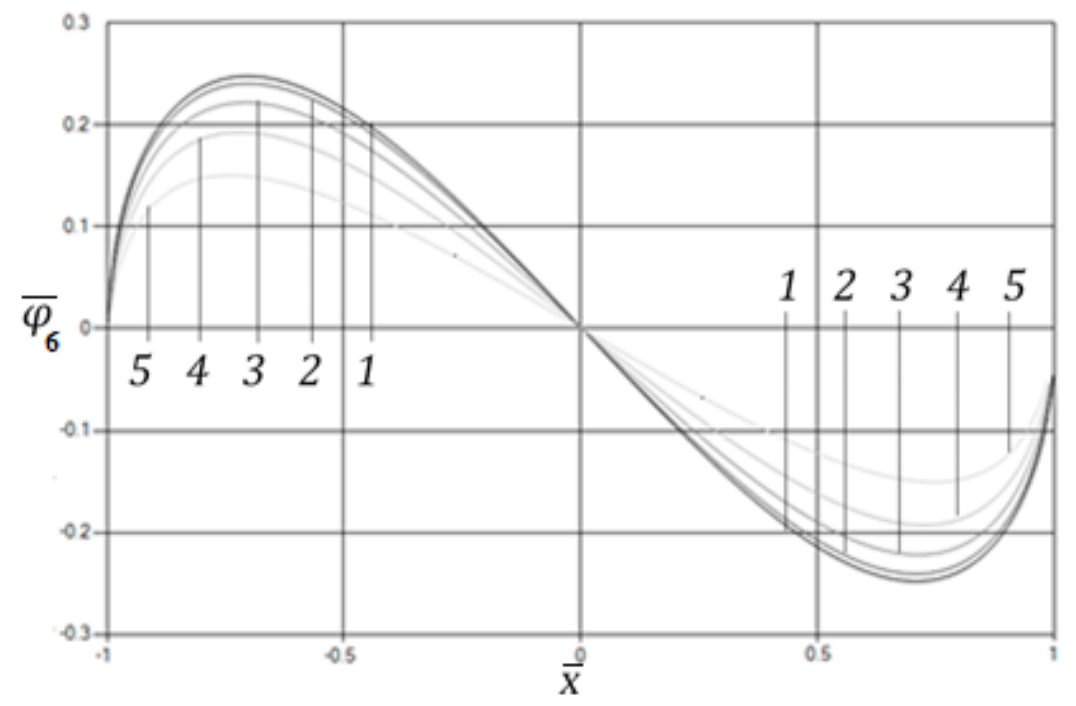

Рис. 5. Графики функции $\overline{\varphi_{6}}(\bar{x})$. для разных углов $\alpha$

(влияние вращательной компоненты скорости $\omega$ ):

$1-\alpha=5^{\circ} ; 2-\alpha=15^{\circ} ; 3-\alpha=30^{\circ} ; 4-\alpha=45^{\circ} ; 5-\alpha=60^{\circ}$

На рис. 6 в качестве примера изображены графики $\bar{\varphi}(\bar{x})$ для различных углов $\alpha ; \quad \bar{\varphi}=\frac{\varphi}{2 a V}=\overline{\varphi_{1}} \frac{U}{V}+\overline{\varphi_{2}}+\overline{\varphi_{6}} \frac{\omega 2 a}{V}$. Здесь со стороны тела влияют все три компоненты скорости, причем принято: $V=1 ; \frac{U}{V}=\frac{1}{3} ; \frac{2 a \omega}{V}=\frac{2}{3}$.

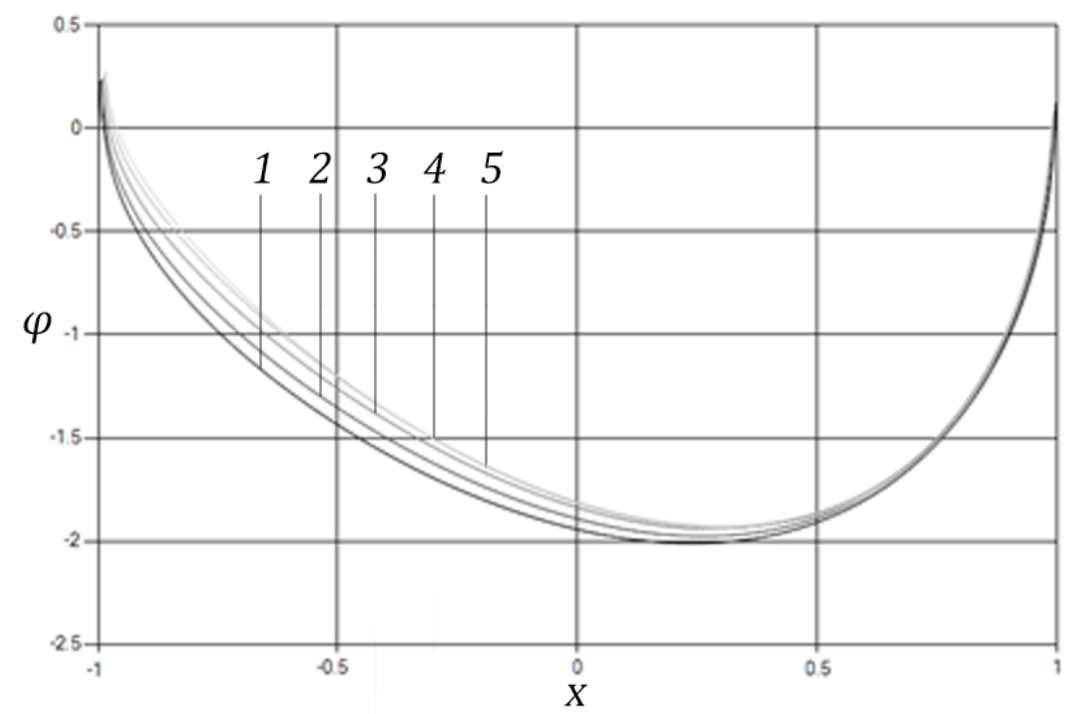

Рис. 6. Графики функции $\bar{\varphi}(\bar{x})$. для разных углов $\alpha$

(влияние трех компонент скоростей $U, V, \omega)$ :

$1-\alpha=5^{\circ} ; 2-\alpha=15^{\circ} ; 3-\alpha=30^{\circ} ; 4-\alpha=45^{\circ} ; 5-\alpha=60^{\circ}$ 
В задаче рассматривались случаи, когда реализуется безотрывное обтекание тела. Однако, как видно из рис. 4, 5, при наличии только одного скоростного фактора $U$ или $\omega$ (а также при их совместном воздействии) на части поверхности тела значение потенциала $\varphi>0$, что свидетельствует о том, что на этих участках поверхности должен возникнуть отрыв. В случае возникновения отрыва задача об ударе должна рассматриваться в другой постановке с учетом наличия точки отрыва в самой постановке.

\section{Библиографические ссылки}

1. Гахов, Ф. Д. Краевые задачи [Текст] / Ф. Д. Гахов. - М.: Наука, 1977. - 640 с.

2. Гоман, О. Г. Ударное взаимодействие несжимаемой жидкости и вертикальной пластины, плавающей на ее поверхности, в условиях образования одной зоны отрыва и наличии вращения [Текст] / О. Г. Гоман, В. А. Катан // Вісн. Дніпр. ун-ту. Сер.: Механіка. 2013. - Вип. 17, т. 1. - С. 191-205.

3. Кочин, Н. Е. Теоретическая гидромеханика в 2-х ч. Часть 1 [Текст] / Н. Е. Кочин, И. А. Кибель, Н. В. Розе. - М.: Гостехиздат, ч. 1. - 1948. - 536 с.

4. Лаврентьев, М. А. Методы теории функций комплексного переменного [Текст] / М. А. Лаврентьев, Б. В. Шабат. - М.: Наука, 1973. - 736 с.

5. Мусхелишвилли, Н. И. Сингулярные интегральные уравнения [Текст] / Н. И. Мусхелишвилли. - М.: Наука, 1968. - 512 с.

6. Седов, Л. И. Плоские задачи гидродинамики и аэродинамики [Текст] / Л. И. Седов. - М.: Наука, 1966. - 448 с.

Надійшла до редколегії 19.06.2018

УдК $532.526: 532.24$

\section{С. В. Алексеенко}

Днепровский национальный университет имени Олеся Гончара

\section{ЧИСЛЕННОЕ МОДЕЛИРОВАНИЕ ОБТЕКАНИЯ КРЫЛА ОNЕRА М6}

A methodology and software-methodical support for describing the processes of flow over bodies by a viscous compressible flow in a three-dimensional formulation on the basis of Reynolds averaged Navier-Stokesequations using the Baldwin-Lomax turbulence model are developed. The discretization of the system of initial Navier-Stokesequations is performed using a finite-dimensional method for curvilinear coordinates. To calculate the convective terms, the Row scheme was used. To provide a second-order accuracy over space, extrapolation with the flow limiter, which is a function of the differences in the parameters at neighboring points proposed by Jameson, was used in the paper. The block-matrix system of algebraic equations was solved by the iterative Gauss-Seidel algorithm. In the calculations a computational grid of type "O" was used, constructed according to algebraic formulas with the use of local interpolation and the method of many surfaces. The outer boundary of the computational domain was the conjugation of a cylindrical and spherical surface. At the boundary of the calculated region coinciding with the wing surface, the conditions for adhesion, non-flow and absence of heat exchange were specified. On the outer boundary, when the boundary conditions were realized, the method of characteristics was used; to calculate the normal velocity component at the boundary, one-dimensional Euler equations in the characteristic form were used. The verification of 